\title{
Morphological and Molecular Variability in Alternaria burnsii and Alternaria alternata Causing Blight Disease of Cummin (Cuminum cyminum L.)
}

\author{
Surendra Singh ${ }^{1}$, Shri Kishan Bairwa ${ }^{2 *}$, Amit Trivedi ${ }^{1}$, Rajesh Kumar Meena ${ }^{1}$, S. C. Meena ${ }^{1}$ and Dasharath Prasad ${ }^{2}$ \\ ${ }^{1}$ Dept. of Plant Pathology, Rajasthan College of Agriculture, Udaipur, Rajasthan, (313 001), India \\ ${ }^{2}$ Agricultural Research Station, SKRAU, Sriganganagar, Rajasthan (335 001), India
}

\section{Article History}

Manuscript No. AR1709

Received in $12^{\text {th }}$ October, 2016

Received in revised form $30^{\text {th }}$ November, 2016

Accepted in final form $6^{\text {th }}$ December, 2016

\section{Correspondence to}

${ }^{*}$ E-mail: kishan.ngr@gmail.com

\section{Keywords}

Alternaria burnsii, Alternaria alternata, molecular variability

\begin{abstract}
A. burnsii and A. alternata showed considerable variations in growth pattern, colony diameter, rate of sporulation and in conidial morphology. Among the isolates of $A$. burnsii maximum colony diameter was observed in UDPAb-1 and least in JSL Ab-3 while in A. alternata maximum colony diameter was observed in isolate JLR Aa-2 and least in JSL Aa-3 after 7 days of incubation. Maximum number of spores $\left(15.2 \times 10^{3}\right.$ conidia $\mathrm{mm}^{-2}$ ) was produced by isolate UDP Ab-1 in A. burnsii and among A. alternata it was maximum in isolate JLR Aa-2 and least $\left(9.2 \times 10^{3}\right.$ conidia $\left.\mathrm{mm}^{-2}\right)$ by JSL Aa-3. Largest conidial size $88-111 \times 26-32 \mu \mathrm{m}$ (with beak) and 30-38×14-18 $\mu \mathrm{m}$ (without beak) was observed in isolates UDP Ab-1 among isolates of $A$. burnsii and smallest conidial size 70-88 $\times 25-32 \mu \mathrm{m}$ (with beak) and 31-39 $\times 15-19 \mu \mathrm{m}$ (without beak) was observed in isolate JLR Ab-1.Whereas, among A. alternata isolates, largest conidial size 38-48 $\times 9-11 \mu \mathrm{m}$ (with beak) and 30-38 $\times 11-14 \mu \mathrm{m}$ (without beak) was observed in isolates JSL Aa-2. Further, molecular variability was assessed using nine RAPD primers and all these 9 primers showed polymorphism. Primers OPB-20, OPC-2 and OPG-17 generated maximum 10 bands with PIC value of $0.31,0.34$ and 0.33 respectively. A total number of 76 amplified bands were obtained and out of them 41 were polymorphic. The maximum and minimum percentage of polymorphism is observed in primers OPC-2 $(80 \%)$ and OPA-19 $(25 \%)$ respectively, these results exhibits the importance of RAPD markers for diversity analysis.
\end{abstract}

\section{Introduction}

Cultivation of cumin (Cuminum cyminum L.) ranked first among all spices with an acreage of around 594 thousand hectares, total production of 394 thousand $\mathrm{mt}$ and productivity of $0.7 \mathrm{mt} \mathrm{ha}^{-1}$ in India (Annonymus, 2016). Cumin is mainly cultivated in various parts of Rajasthan, Gujarat and Maharashtra, during winter season with suitable agronomic practices to achieve highest production. But its sustainable cultivation is continuously challenged by various diseases like blight (Alternaria burnsii Uppal, Patel and Kamat), wilt (Fusarium oxysporum f.sp. cumini Patel, Prasad, Mathur and Mathur) and powdery mildew (Erysiphe polygoni DC ex. St.Am.) causing quantitative and qualitative yield loss (Holliday, 1980). Among these, Alternaria blight is considered to be the most devastating to cumin and is quite prevalent. It appears in very destructive form as it affects all above ground plant parts including seed, thus, causing havoc yield loss. Rastogi (1993) isolated A. brunsii from contaminated black colored seeds of cumin in 47 samples out of 105 samples collected from 16 districts of Rajasthan, India. Losses up to $70 \%$ have been reported (Holliday, 1980). Mixed inoculum of A. brunsii and $A$. alternata causes higher reduction in yield up to $54.8 \%$ (Surendra et al., 2015).

Variability studies are important to document the changes occurring in populations and individuals as variability indicate the existence of different pathotypes. Dubey et al. (2016) observed variability in physical and chemical properties of cumin seed samples collected from cumin growing areas located in the 7 districts of Rajasthan and 5 districts of Gujarat classified under Agro-Ecological Sub Regions (AESR) of India. The variability is a well known phenomenon in genus Alternaria and may be noticed as changes in spore shape and size, growth and sporulation, pathogenicity, etc. Pathogen population structure and mechanisms by which variation arises within a population is of paramount importance for devising a successful disease management strategy. This requires continuous monitoring of the development of pathogen 
variability more so for the breeding programme aimed at developing resistant genotypes to the given set of pathogenic races. Variation in pathogen populations can generally be detected with methods like cultural, morphological, pathogenic and molecular variability. Hence, the present investigations were carried out to study the variability in Alternaria burnsi (Uppal) and Alternaria alternata (Kessler) causing blight disease.

\section{Materials and Methods}

The study was carried out at Department of Plant Pathology, Rajasthan College of Agriculture (RCA), Udaipur, Rajasthan (India) during 2012-13 and 2013-14. Disease samples of blighted cumin plants were collected during rabi 2011 from Jalore (2011), RCA Udaipur (2011) and Jaisalmer (2011) of Rajasthan all from local land races. The main aim was to explore possibility of existence of different spp. and/or variables of Alternaria blight pathogen. The infected aerial parts of the diseased samples were carefully placed in polythene bags, properly tagged and brought to the laboratory. Isolations of the pathogen were attempted from all samples. These infected aerial parts were thoroughly washed in running tap water to remove the adhering soil. These were then cut into small pieces with the help of a sterilized scalpel, washed in sterilized water, surface sterilized by dipping in $0.1 \%$ mercuric chloride $\left(\mathrm{HgCl}_{2}\right)$ solution for two minutes rinsed thrice in sterilized distilled water and transferred on potato dextrose agar (PDA) medium in Petri plates. The plates were incubated at $28 \pm 1{ }^{\circ} \mathrm{C}$ for growth. Sub cultures were made from the periphery of the mycelial growth which appeared after 3-4 days. The list of the isolates recovered is given in Table 1.

\subsection{Cultural and morphological characters of isolates of Alternaria burnsii and Alternaria alternate}

The nine isolates of $A$. burnsii and nine isolates of $A$. alternata were grown on Potato Dextrose Agar (PDA) and Richard's agar medium. The autoclaved medium was dispensed in plate and allowed to solidify. Five mm disc of the individual isolate of $A$. burnsii and A. alternata removed from the periphery of seven day old culture and was aseptically placed in the centre of the PDA and Richards's agar plate, keeping five plates as five replications for each isolate. The plates were incubated at $28 \pm 1^{\circ} \mathrm{C}$. The variations in growth pattern and colony diameter in all isolates were recorded. Spore production by each isolate was determined by removing agar-plugs ( $5 \mathrm{~mm}$ diameter) from three liner spots across the centre of the colony, which were suspended in $10 \mathrm{ml}$ sterile water in glass test tube and agitated twice for about 10 seconds each time on a vortex shaker to dislodge conidia. The number of conidia in the resultant suspensions was determined using a haemocytometer and expressed as number of conidia $\mathrm{mm}^{-2}$ of medium. For spore
Table 1: Isolates of Alternaria burnsii and Alternaria alternata recovered from samples collected from fields in cumin growing areas of Rajasthan

\begin{tabular}{lllll}
\hline $\begin{array}{l}\text { Sl. } \\
\text { No. }\end{array} \begin{array}{l}\text { Place of } \\
\text { collection }\end{array}$ & Code & $\begin{array}{l}\text { Pathogens } \\
\text { isolated }\end{array}$ & $\begin{array}{l}\text { Isolate } \\
\text { designation }\end{array}$ \\
\hline 1. & RCA, Udaipur & UDP & A. burnsii & UDP Ab-1 \\
& & & & UDP Ab-2 \\
& & & UDP Ab-3 \\
& & & A. alternate & UDP Aa-1 \\
& & & UDP Aa-2 \\
& & & UDP Aa-3 \\
2. Jaisalmer & JSL & A. burnsii & JSL Ab-1 \\
& & & JSL Ab-2 \\
& & & JSL Ab-3 \\
& & & A. alternate & JSL Aa-1 \\
& & & JSL Aa-2 \\
& & & JSL Aa-3 \\
3. Jalore & JLR & A. burnsii & JLR Ab-1 \\
& & & JLR Ab-2 \\
& & & JLR Ab-3 \\
& & A. alternate & JLR Aa-1 \\
& & & JLR Aa-2 \\
& & & JLR Aa-3 \\
\hline
\end{tabular}

size (length and width) mounts were prepared in aniline-blue lacto-phenol and measurements were taken by measuring 50 spores of each isolates using stage and ocular micrometer.

\subsection{Molecular variability (RAPD)}

For molecular variability nine RAPD primers were used to assess nine isolates of Alternaria burnsii and nine isolates of Alternaria alternata. These isolates were obtained from Rajasthan College of Agriculture farm Udaipur, Jaisalmer and Jalore and further named as (UDP Ab-1), (UDP Ab-2), (UDP Ab-3), ), (JSL Ab-1), (JSL Ab-2), (JSL Ab-3), (JLR Ab-1), (JLR Ab-2), (JLR Ab-3) and (UDP Aa-1), (UDP Aa-2), (UDP Aa-3), (JSL Aa-1), (JSL Aa-2), (JSL Aa-3), (JLR Aa-1), (JLR Aa-2), (JLR Aa-3) respectively for convenience. Molecular work was carried out at Escherichia Genomics Research Laboratories in New Delhi. DNA was extracted from fungal mycelium using CTAB method as described by Doyle and Doyle (1987) with slight modifications. DNA was amplified with RAPD primer (Table 1a) using PCR technique. The bands were scored for their presence and absence.

\subsection{Statistical analysis for similarity coefficient}

The scores ( 0 or 1$)$ for each band obtained from photograph were entered in the form of a rectangular data matrix (qualitative data matrix). The pair-wise association coefficients 


\begin{tabular}{|c|c|c|c|}
\hline \multicolumn{4}{|c|}{ Table 1a: List of primers used for the RAPD analysis } \\
\hline S1. No. & Primer & Sequence (5'-3') & Bases \\
\hline 1. & OPA-05 & 5`AGGGGTCTTG3` & 10 \\
\hline 2. & OPA-19 & 5'-CAAACGTCGG-3' & 10 \\
\hline 3. & OPB-07 & $5^{`}-$ GGTGACGCAG-3` & 10 \\
\hline 4. & OPB-13 & 5'-TTCCCCCGCT-3’ & 10 \\
\hline 5. & OPB-19 & 5'-ACCCCCGAAG-3' & 10 \\
\hline 6. & OPB-20 & 5'-GGACCCTTAC-3' & 10 \\
\hline 7. & OPC- 2 & $5^{`}$ - GTGAGGCGTC-3` & 10 \\
\hline 8. & OPG-16 & 5'-AGCGTCCTCC-3’' & 10 \\
\hline 9. & OPG-17 & $5^{\prime}$-ACGACCGACA3' & 10 \\
\hline
\end{tabular}

were calculated from qualitative data matrix using Jaccard's similarity coefficient. The equation for calculating Jaccard's similarity coefficients ' $F$ ' between two samples A and B is:

$\mathrm{f}=\mathrm{n}_{\mathrm{xy}} /\left(\mathrm{n}_{1}-\mathrm{n}_{\mathrm{z}}\right)$

Where,

$\mathrm{n}_{\mathrm{xy}}=$ No. of bands common to sample A and sample B

$\mathrm{n}_{1}=$ Total number of bands present in all samples

$\mathrm{n}_{\mathrm{z}}=$ No.of bands not present in sample A or B but found in other samples.

Cluster analysis for the genetic distance was then carried out using UPGMA (Unweighted Pair Group Method with Arithmetic Mean) clustering method. The genetic distances obtained from cluster analysis through UPGMA were used to construct the dendrogram, depicting the relationships of the clones using computer program NTSYS pc version 2.02 (Rohlf, 1998).

\section{Results and Discussion}

Researcher are continue trying to control Alternaria blight by using chemicals, but due to the variability in the pathogen strain, this disease is still not completely removed from farmer field. Due to the dispersion of this pathogen in all form viz., air, seed and soil born it is serious challenge to plant pathologist as well as others. Thus the accurate identification of strain or races is essential to know the mechanism of survival of pathogen. Assessment of variability is essential for correct prediction of pathogen to survival, dissemination and development of the disease. Thus, in present study total 18 diverse isolates were used to check the variability and further research on field application using morphological and molecular markers.

\subsection{Cultural and morphological character of isolates}

Nine isolates of each of A. burnsii and A. alternata collected from three different locations viz., Udaipur, Jaisalmer and Jalore, exhibited variations in colony diameter, size, colour of the colony and rate of sporulation on PDA medium at $28 \pm 1{ }^{\circ} \mathrm{C}$ after 7 days of incubation. Among the species of
A. burnsii isolates collected from Udaipur shows maximum colony diameter $89.4 \mathrm{~mm}$ i.e., UDP Ab-1, followed by 88.2 $\mathrm{mm}$ in UDP Ab-2, $86.6 \mathrm{~mm}$ in UDP Ab-3. Among Jaisalmer isolates $80.4 \mathrm{~mm}$ colony diameter was recorded in JSL Ab-1, followed by $79.4 \mathrm{~mm}$ in JSL Ab-2 and $77.0 \mathrm{~mm}$ was observed with JSL Ab-3, Among the Jalore isolates JLR Ab-1 showed $87.1 \mathrm{~mm}$ colony diameter, followed by $85.9 \mathrm{~mm}$ in JLR Ab-2, $83.1 \mathrm{~mm}$ in JLR Ab-3. (Table 2)

In the isolates of $A$. burnsii Udaipur isolates showing the maximum number of conidia $15.2 \times 10^{3}$ conidia $\mathrm{mm}^{-2}$ in UDP $\mathrm{Ab}-1$, followed by $14.2 \times 10^{3}$ conidia $\mathrm{mm}^{-2}$ by UDP $\mathrm{Ab}-2$, $12.9 \times 10^{3}$ conidia $\mathrm{mm}^{-2}$ UDP Ab-3. In isolates of Jaisalmer $11.2 \times 10^{3}$ conidia $\mathrm{mm}^{-2}$ in JSL Ab- 1 , followed by $10.4 \times 10^{3}$ conidia $\mathrm{mm}^{-2}$ in JSL Ab-2, $10.9 \times 10^{3}$ conidia mm ${ }^{-2}$ in JSL Ab-3. Similarly in isolates of Jalore $13.3 \times 10^{3}$ conidia $\mathrm{mm}^{-2}$ in JLR Ab-1, followed by $12.0 \times 10^{3}$ conidia mm ${ }^{-2}$ JLR Ab-2, $11.9 \times 10^{3}$ conidia $\mathrm{mm}^{-2}$ in JLR Ab-3, (Table 3).

Among the A. alternata isolates collected from Udaipur maximum colony diameter $85.1 \mathrm{~mm}$ in UDP Aa-1, followed by $83.9 \mathrm{~mm}$ in UDP Aa-2, $82.3 \mathrm{~mm}$ in UDP Aa-3. However, the isolates of Jaisalmer $76.2 \mathrm{~mm}$ in JSL Aa-1, followed by $75.0 \mathrm{~mm}$ in JSL Aa-2, $73.3 \mathrm{~mm}$ was observed with JSL Aa-3, whereas, the isolates of Jalore $85.2 \mathrm{~mm}$ was observed with JLR Aa-2, followed by $83.6 \mathrm{~mm}$ in JLR Aa-1, $83.5 \mathrm{~mm}$ in JLR Aa-3 (Table 4). Moreover, the isolates of $A$. alternata collected from Udaipur the maximum number of conidia $13.3 \times 10^{3}$ conidia/ $\mathrm{mm}^{2}$ were produced in isolate UDP Aa-1, followed by $12.1 \times 10^{3}$ conidia $\mathrm{mm}^{-2}$ by UDP Aa-2, $11.0 \times 10^{3}$ conidia $\mathrm{mm}^{-2}$ in UDP Aa-3, Among the isolates of Jaisalmer $11.0 \times 10^{3}{\text { conidia } \mathrm{mm}^{-2}}^{-2}$ in JSL Aa-1, followed by $10.1 \times 10^{3}$ conidia $\mathrm{mm}^{-2}$ in JSL Aa-2, $9.2 \times 10^{3}$ conidia $\mathrm{mm}^{-2}$ in JSL Aa-3. Further, the isolates of Jalore $14.0 \times 10^{3}$ conidia $\mathrm{mm}^{-2}$ in JLR Aa- 2 , followed by $12.0 \times 10^{3}$ conidia $\mathrm{mm}^{-2}$ in JLR Aa- $1,11.6 \times 10^{3}$ conidia $\mathrm{mm}^{-2}$ in JLR Aa3 , sporulation was recorded (Table 5). Colony characters i.e. margin/shape and colour of the cultures of individual isolate of $A$. burnsii are given in Table 2 .

\subsection{Growth on Richards agar media}

The nine isolates of $A$. burnsii and nine isolates of $A$. alternata collected from three different locations viz., Udaipur, Jaisalmer and Jalore, three isolates of each species collected from each location exhibited variations in colony diameter, size, colour of the colony and rate of sporulation on Richards Agar medium at $28 \pm 1{ }^{\circ} \mathrm{C}$ after 7 days of inoculation.

Among the species of $A$. burnsii isolates collected from Udaipur, maximum colony diameter $88.7 \mathrm{~mm}$ was observed with UDP Ab-1, followed by $87.4 \mathrm{~mm}$ in UDP Ab-2, 85.2 $\mathrm{mm}$ in UDP Ab-3. In Jaisalmer, isolates $81.8 \mathrm{~mm}$ in JSL Ab3, followed by $80.4 \mathrm{~mm}$ in JSL Ab-2, $78.8 \mathrm{~mm}$ was observed with JSL Ab-1, Among the Jalore isolates JLR Ab-1 showed 
Table 2: Radial growth and cultural characters of nine isolates of $A$. burnsii on PDA

\begin{tabular}{|c|c|c|c|c|}
\hline $\begin{array}{l}\text { Sl. } \\
\text { No. }\end{array}$ & Isolates & $\begin{array}{c}\text { Diame- } \\
\text { ter }^{*}(\mathrm{~mm}) \\
7^{\text {th }} \text { days }\end{array}$ & $\begin{array}{c}\text { Sporula- } \\
\operatorname{tion}^{* *}\left(\times 10^{3} \mathrm{~mm}^{-2}\right. \\
\text { medium })\end{array}$ & Growth characters and colony colour \\
\hline 1. & UDPAb-1 & 89.4 & 15.2 & Cottony felty aerial growth, without zonation, white regular margin. \\
\hline 2. & UDPAb-2 & 88.2 & 14.2 & $\begin{array}{l}\text { Cottony submerged growth, dark greyish, without zonation with white } \\
\text { regular margin. }\end{array}$ \\
\hline 3. & UDPAb-3 & 86.6 & 12.9 & $\begin{array}{l}\text { Felty cottony mycelia growth grey coloured, zonation present with white } \\
\text { regular margin. }\end{array}$ \\
\hline 4. & JSL Ab-1 & 80.4 & 11.2 & $\begin{array}{l}\text { Velvety submerged growth, without zonation, white regular margin, steel } \\
\text { grey in centre. }\end{array}$ \\
\hline 5. & JSL Ab-2 & 79.4 & 10.4 & $\begin{array}{l}\text { Velvety submerged growth, without zonation, white regular margin, steel } \\
\text { grey in centre. }\end{array}$ \\
\hline 6. & JSL Ab-3 & 77.0 & 10.1 & $\begin{array}{l}\text { Cottony velvety suppressed growth, light zonation present with off white } \\
\text { and kight grey in centre, white regular margin. }\end{array}$ \\
\hline 7. & JLR Ab-1 & 87.1 & 13.3 & $\begin{array}{l}\text { Felty suppressed olivaceous uniform growth, light zonation present, off } \\
\text { white regular margin pale grey in centre. }\end{array}$ \\
\hline 8. & JLR Ab-2 & 85.9 & 12.0 & $\begin{array}{l}\text { Cottony felty suppressed white and grayish mycelia growth with white } \\
\text { regular margin. }\end{array}$ \\
\hline 9. & JLR Ab-3 & 83.1 & 11.9 & Aerial felty flocose light olivaceous green to dull black, white regular margin. \\
\hline \multicolumn{2}{|c|}{$\mathrm{SEm} \pm$} & 1.23 & 0.39 & \\
\hline \multicolumn{2}{|c|}{$\mathrm{CD}(p \leq 0.05)$} & 3.68 & 1.19 & \\
\hline \multicolumn{2}{|c|}{$\mathrm{CV} \%$} & 2.53 & 5.55 & \\
\hline
\end{tabular}

"Mean of three replications; ${ }^{* *}$ Mean of three replications, three from each of the plate

Table 3: Variation in conidial morphology of nine isolates of $A$. burnsii on PDA

\begin{tabular}{|c|c|c|c|c|c|c|c|c|}
\hline \multirow[t]{3}{*}{ Isolate } & \multicolumn{4}{|c|}{ Conidial morphology with beak $(\mu \mathrm{m})$} & \multicolumn{4}{|c|}{ Conidial morphology without beak $(\mu \mathrm{m})$} \\
\hline & \multicolumn{2}{|c|}{ Length } & \multicolumn{2}{|c|}{ Width } & \multicolumn{2}{|c|}{ Length } & \multicolumn{2}{|c|}{ Width } \\
\hline & Mean & Range & Mean & Range & Mean & Range & Mean & Range \\
\hline UDPAb-1 & $99.6 \pm 4.61$ & $88-111$ & $29.3 \pm 1.35$ & $26-32$ & $34.6 \pm 1.60$ & $30-38$ & $16.5 \pm 0.76$ & $14-18$ \\
\hline UDPAb-2 & $96.5 \pm 5.14$ & $85-108$ & $30.0 \pm 1.59$ & $26-33$ & $36.6 \pm 1.9$ & $32-40$ & $17.2 \pm 0.91$ & $15-19$ \\
\hline UDPAb-3 & $93.4 \pm 4.85$ & $83-104$ & $32.4 \pm 1.68$ & $28-36$ & $35.2 \pm 1.82$ & $31-39$ & $15.2 \pm 0.78$ & $13-17$ \\
\hline JSL Ab-1 & $88.9 \pm 4.62$ & $79-99$ & $36.0 \pm 1.87$ & $32-40$ & $37.5 \pm 1.94$ & $33-42$ & $17.0 \pm 0.88$ & $15-19$ \\
\hline JSL Ab-2 & $83.4 \pm 4.35$ & $74-93$ & $35.1 \pm 1.83$ & $31-39$ & $38.2 \pm 1.99$ & $34-42$ & $16.0 \pm 0.83$ & $14-17$ \\
\hline JSL Ab-3 & $86.4 \pm 4.00$ & $76-96$ & $37.1 \pm 1.72$ & $33-41$ & $36.0 \pm 1.66$ & $32-40$ & $15.4 \pm 0.71$ & $13-17$ \\
\hline JLR Ab-1 & $78.8 \pm 3.65$ & $70-88$ & $29.0 \pm 1.34$ & $25-32$ & $34.8 \pm 1.61$ & $31-39$ & $17.1 \pm 0.79$ & $15-19$ \\
\hline JLR Ab-2 & $84.0 \pm 4.47$ & $74-94$ & $28.0 \pm 1.49$ & 24-31 & $34.0 \pm 1.81$ & $30-38$ & $19.0 \pm 1.01$ & $16-21$ \\
\hline JLR Ab-3 & $82.8 \pm 4.30$ & $73-92$ & $27.6 \pm 1.43$ & $24-30$ & $37.0 \pm 1.92$ & $32-41$ & $16.2 \pm 0.84$ & $14-18$ \\
\hline $\operatorname{SEm} \pm$ & 0.23 & & 0.09 & & 0.11 & & 0.05 & \\
\hline $\mathrm{CD}(p \leq 0.05)$ & 0.75 & & 0.27 & & 0.30 & & 0.14 & \\
\hline $\mathrm{CV} \%$ & 2.19 & & 2.22 & & 2.17 & & 2.19 & \\
\hline
\end{tabular}

${ }^{*}$ Mean no. of 50 conidia and \pm S.D. of mean value

$85.9 \mathrm{~mm}$ colony diameter, followed by $84.0 \mathrm{~mm}$ in JLR Ab-2, $83.0 \mathrm{~mm}$ in JLR Ab-3 (Table 6).

Among the isolates of $A$. burnsii collected from Udaipur the maximum no. of conidia $15.0 \times 10^{3} \mathrm{~mm}^{2}$ were produced by isolate UDP $\mathrm{Ab}-1$, followed by $14.3 \times 10^{3}$ conidia $\mathrm{mm}^{-2}$ by UDP $\mathrm{Ab}-2,12.6 \times 10^{3}$ conidia $\mathrm{mm}^{-2}$ UDP Ab-3. Among the isolates 


\begin{tabular}{|c|c|c|c|c|}
\hline $\begin{array}{l}\text { Sl. } \\
\text { No. }\end{array}$ & Isolate & $\begin{array}{c}\text { Diameter* } \\
(\mathrm{mm}) 7^{\text {th }} \\
\text { days }\end{array}$ & $\begin{array}{c}\text { Sporulation } \\
\left(\times 103 \mathrm{~mm}^{-2}\right. \\
\text { medium })\end{array}$ & Growth characters and colony colour \\
\hline 1. & UDPAa-1 & 85.1 & 13.3 & $\begin{array}{l}\text { Aerial light olivaceous uniform growth, light zonation present, white regular } \\
\text { margin. }\end{array}$ \\
\hline 2. & UDPAa-2 & 83.9 & 12.1 & $\begin{array}{l}\text { Cottony light grey to olive green in centre, clear zonation present with regular } \\
\text { white margin. }\end{array}$ \\
\hline 3. & UDPAa-3 & 82.3 & 11.0 & $\begin{array}{l}\text { Aerial felty mycelial growth, zonation present, steel grey in centre with white } \\
\text { regular margin. }\end{array}$ \\
\hline 4. & JSL Aa-1 & 76.2 & 11.0 & $\begin{array}{l}\text { Felty velvety suppressed growth, dull black or dark grey in centre, clear zonation } \\
\text { present with white regular margin }\end{array}$ \\
\hline 5. & JSL Aa-2 & 75.0 & 10.1 & $\begin{array}{l}\text { Cottony velvety submerged growth, white or dark grey in colour, without } \\
\text { zonation, white regular margin but sometimes irregular. }\end{array}$ \\
\hline 6. & JSL Aa-3 & 73.3 & 9.2 & $\begin{array}{l}\text { Felty velvety cottony and grayish mycelia growth, light zonation present, } \\
\text { sometimes dull white towards margin. }\end{array}$ \\
\hline 7. & JLR Aa-1 & 83.6 & 12.0 & $\begin{array}{l}\text { Aerial velvety cottony pure white uniform mycelial growth, without zonation, } \\
\text { light grey in centre. }\end{array}$ \\
\hline 8. & JLR Aa-2 & 85.2 & 14.0 & $\begin{array}{l}\text { Cottony velvety submerged uniform mycelial growth, pure white colour, } \\
\text { without zonztion }\end{array}$ \\
\hline 9. & JLR Aa-3 & 83.5 & 11.6 & $\begin{array}{l}\text { Aerial cottony submerged growth, white in centre and sometimes light brown } \\
\text { at periphery. }\end{array}$ \\
\hline \multicolumn{2}{|c|}{$\mathrm{SEm} \pm$} & 1.23 & 0.19 & \\
\hline \multicolumn{2}{|c|}{$\mathrm{CD}(p \leq 0.05)$} & 3.70 & 1.39 & \\
\hline \multicolumn{2}{|c|}{ CV\% } & 2.65 & 6.95 & \\
\hline
\end{tabular}

*: Mean of three replications; ${ }^{* *}:$ Mean of three replications, three from each of the plate

\begin{tabular}{|c|c|c|c|c|c|c|c|c|c|}
\hline \multirow[t]{3}{*}{ Sl. No. } & \multirow[t]{3}{*}{ Isolate } & \multicolumn{4}{|c|}{ Conidial morphology with beak $(\mu \mathrm{m})$} & \multicolumn{4}{|c|}{ Conidial morphology without beak $(\mu \mathrm{m})$} \\
\hline & & \multicolumn{2}{|c|}{ Length } & \multicolumn{2}{|c|}{ Width } & \multicolumn{2}{|c|}{ Length } & \multicolumn{2}{|c|}{ Width } \\
\hline & & Mean & Range & Mean & Range & Mean & Range & Mean & Range \\
\hline 1. & UDP Aa-1 & $27.1 \pm 1.41$ & $24-30$ & $13.1 \pm 0.68$ & $11-14$ & $20.5 \pm 1.07$ & $18-22$ & $13.4 \pm 0.70$ & $11-15$ \\
\hline 2. & UDP Aa-2 & $33.5 \pm 1.55$ & $29-37$ & $11.1 \pm 0.51$ & $9-12$ & $28.6 \pm 1.32$ & $25-32$ & $11.5 \pm 0.53$ & $10-12$ \\
\hline 3. & UDP Aa-3 & $37.5 \pm 2.00$ & $33-42$ & $12.0 \pm 0.64$ & $10-13$ & $24.7 \pm 2.30$ & $15-34$ & $12.3 \pm 0.65$ & $10-13$ \\
\hline 4. & JSL Aa-1 & $36.9 \pm 1.97$ & $32-41$ & $11.8 \pm 0.63$ & $10-13$ & $24.7 \pm 1.31$ & $22-27$ & $11.4 \pm 0.61$ & $10-12$ \\
\hline 5. & JSL Aa-2 & $43.4 \pm 2.25$ & $38-48$ & $10.6 \pm 0.55$ & $9-11$ & $34.5 \pm 1.79$ & $30-38$ & $12.5 \pm 0.65$ & $11-14$ \\
\hline 6. & JSL Aa-3 & $26.3 \pm 1.37$ & $23-29$ & $12.7 \pm 0.66$ & $11-14$ & $29.8 \pm 1.55$ & $26-33$ & $13.5 \pm 0.70$ & $12-15$ \\
\hline 7. & JSL Aa-1 & $25.9 \pm 1.20$ & $23-29$ & $12.6 \pm 0.63$ & $11-14$ & $19.0 \pm 0.88$ & $16-21$ & $12.8 \pm 0.59$ & $11-14$ \\
\hline 8. & JSL Aa-2 & $32.0 \pm 1.70$ & $28-35$ & $10.6 \pm 0.55$ & $9-11$ & $27.0 \pm 1.43$ & $24-30$ & $10.0 \pm 0.53$ & $8-11$ \\
\hline \multirow[t]{4}{*}{9.} & JSL Aa-3 & $35.8 \pm 1.86$ & $31-40$ & $11.1 \pm 0.66$ & $9-12$ & $23.6 \pm 1.22$ & $21-26$ & $11.5 \pm 0.60$ & $10-12$ \\
\hline & $\mathrm{SEm} \pm$ & 0.10 & & 0.03 & & 0.11 & & 0.03 & \\
\hline & $\begin{array}{l}\mathrm{CD} \\
(p \leq 0.05)\end{array}$ & 0.28 & & 0.09 & & 0.33 & & 0.09 & \\
\hline & $\mathrm{CV} \%$ & 2.18 & & 2.04 & & 0.25 & & 2.05 & \\
\hline
\end{tabular}

*Mean number of 50 conidia and \pm S.D. of mean value 


\begin{tabular}{|c|c|c|c|c|}
\hline $\begin{array}{l}\text { Sl. } \\
\text { No. }\end{array}$ & Isolate & $\begin{array}{l}\text { Diame- } \\
\text { ter* }^{*}(\mathrm{~mm}) \\
7^{\text {th }} \text { days }\end{array}$ & $\begin{array}{l}\text { Sporulation } \\
\left(\times 103 \mathrm{~mm}^{-2}\right. \\
\text { medium })\end{array}$ & Growth characters and colony colour \\
\hline 1. & UDPAb-1 & 88.7 & 15.0 & $\begin{array}{l}\text { Cottony velvety suppressed mycelia growth, zonation present, pure white in } \\
\text { centre with irregular margin. }\end{array}$ \\
\hline 2. & UDPAb-2 & 87.4 & 14.3 & $\begin{array}{l}\text { Felty aerial suppressed light brown olivaceous sometimes dull white, highly } \\
\text { suppressed at margin, regular white margin. }\end{array}$ \\
\hline 3. & UDPAb-3 & 85.2 & 12.6 & $\begin{array}{l}\text { Velvety cottony suppressed growth, without zonation, light brown in centre with } \\
\text { dull white regular margin. }\end{array}$ \\
\hline 4. & JSL Ab-1 & 78.8 & 10.3 & $\begin{array}{l}\text { Felty aerial cottony mycelia growth light zonation, dull white irregular margin } \\
\text { and light grey or brown in centre. }\end{array}$ \\
\hline 5. & JSL Ab-2 & 80.4 & 11.1 & $\begin{array}{l}\text { Velvety aerial at centre, submerged suppressed mycelia growth, clear zonation } \\
\text { present, dark grey in centre later turned in to dull black with irregular off white } \\
\text { margin. }\end{array}$ \\
\hline 6. & JSL Ab-3 & 81.8 & 11.2 & $\begin{array}{l}\text { Aerial cottony pure white in centre, light zonation present, off white regular } \\
\text { margin while light brown at centre. }\end{array}$ \\
\hline 7. & JLR Ab-1 & 85.9 & 13.8 & $\begin{array}{l}\text { Aerial felty mycelia growth, zonation present, dull black in centre with white } \\
\text { regular margin. }\end{array}$ \\
\hline 8. & JLR Ab-2 & 84.0 & 12.0 & $\begin{array}{l}\text { Aerial cottony, submerged uniform growth, sometime pale olive brown at } \\
\text { periphery with pure white in centre without zonation }\end{array}$ \\
\hline 9. & JLR Ab-3 & 83.0 & 11.9 & $\begin{array}{l}\text { Cottony velvety submerged growth, clear zonation present, dull black and dark } \\
\text { grey in centre with irregular margin and little white near margin. }\end{array}$ \\
\hline \multicolumn{2}{|c|}{$\mathrm{SEm} \pm$} & 1.45 & 0.41 & \\
\hline \multicolumn{2}{|c|}{$\mathrm{CD}(p \leq 0.05)$} & 4.35 & 1.24 & \\
\hline \multicolumn{2}{|c|}{$\mathrm{CV} \%$} & 3.0 & 5.74 & \\
\hline
\end{tabular}

${ }^{*}:$ Mean of three replications; ${ }^{* *}$ : Mean of three replications, three from each of the plate

of Jaisalmer $11.2 \times 10^{3}$ conidia $\mathrm{mm}^{-2}$ in JSL Ab-1, followed by $11.1 \times 10^{3}$ conidia $\mathrm{mm}^{-2}$ in JSL Ab-2, $10.3 \times 10^{3}$ conidia $\mathrm{mm}^{-2}$ in JSL Ab-1. Among the isolates of Jalore $13.8 \times 10^{3}{\text { conidia } \mathrm{mm}^{-2}}^{-2}$ in JLR Ab-1, followed by $12.0 \times 10^{3}$ conidia $\mathrm{mm}^{-2} \mathrm{JLR} \mathrm{Ab}-2$, $11.9 \times 10^{3}$ conidia $\mathrm{mm}^{-2}$ in JLR Ab-3 (Table 7).

Among the species of $A$. alternata isolates collected from Udaipur maximum colony diameter $87.7 \mathrm{~mm}$ in UDP Aa-3, followed by $86.3 \mathrm{~mm}$ in UDP Aa-2, $84.3 \mathrm{~mm}$ in UDP Aa3. Among the isolates of Jaisalmer $75.5 \mathrm{~mm}$ in JSL Aa-1, followed by $74.2 \mathrm{~mm}$ in JSL Aa-2, $72.9 \mathrm{~mm}$ was observed with JSL Aa-3, among the isolates of Jalore $84.7 \mathrm{~mm}$ was observed with JLR Aa-3, followed by $84.0 \mathrm{~mm}$ in JLR Aa-2, $82.3 \mathrm{~mm}$ in JLR Aa-3 (Table 8).

Among the isolates of A. alternata collected from Udaipur the maximum number of conidia14.2 $\times 10^{3} \mathrm{~mm}^{2}$ were produced in isolate UDP Aa- 3 , followed by $13.7 \times 10^{3}$ conidia $\mathrm{mm}^{-2}$ by UDP Aa-2, $10.8 \times 10^{3}$ conidia $\mathrm{mm}^{-2}$ in UDP Aa-1, Among the isolates of Jaisalmer $10.2 \times 10^{3}$ conidia $\mathrm{mm}^{-2}$ in JSL Aa- 1 , followed by $10.0 \times 10^{3}$ conidia $\mathrm{mm}^{-2}$ in JSL Aa- $2,9.8 \times 10^{3}$ conidia $\mathrm{mm}^{-2}$ in JSL Aa-3. Among the isolates of Jalore $13.4 \times 10^{3}$ conidia $\mathrm{mm}^{-2}$ in JLR Aa-3, followed by $10.7 \times 10^{3}$ conidia $\mathrm{mm}^{-2}$ in JLR
Aa- $2,10.2 \times 10^{3}$ conidia $\mathrm{mm}^{-2}$ in JLR Aa-1, sporulation was recorded (Table 9).

Colony characters i.e. margin/shape and colour of the culture of individual isolates of $A$. burnsii are shown in table-8. Morphological characters of nine isolates of $A$. burnsii were similar to standard description given by Holliday (1980). The spore characteristics of individual isolates are presented in Table 7.

Colony characters i.e. margin/shape and colour of the culture of individual isolates of A. alternata are shown in Table-8. The morphological characters of nine isolates of A. alternata were similar to standard description given by Holliday (1980). Pryor and Michailides (2002) reported similar culture conditions for characterization of colony morphology and sporulation habit among small-spored catenulate Alternaria spp.The spore characteristics of individual isolates are given in Table 9. Our characters are similar with Pandey et al. (2005) where, they concluded that variability in Alternaria solani exists only with respect to cultural characters. Eleven isolates of $A$. solan $i$ causing early blight of tomato showed cultural variability in respect of radial growth, growth rate day ${ }^{-1}$ and pigmentation on potato dextrose agar. These results are also in similarity with 
Table 7: Variation in conidial morphology of nine isolates of A. burnsii on RAM

\begin{tabular}{|c|c|c|c|c|c|c|c|c|c|}
\hline \multirow[t]{3}{*}{ Sl. No. } & \multirow[t]{3}{*}{ Isolate } & \multicolumn{4}{|c|}{ Conidial morphology with beak $(\mu \mathrm{m})$} & \multicolumn{4}{|c|}{ Conidial morphology without beak $(\mu \mathrm{m})$} \\
\hline & & \multicolumn{2}{|c|}{ Length } & \multicolumn{2}{|c|}{ Width } & \multicolumn{2}{|c|}{ Length } & \multicolumn{2}{|c|}{ Width } \\
\hline & & Mean & Range & Mean & Range & Mean & Range & Mean & Range \\
\hline 1. & UDPAa-1 & $99.1 \pm 4.59$ & $88-111$ & $30.9 \pm 1.43$ & $27-34$ & $36.2 \pm 1.6$ & $32-40$ & $17.8 \pm 0.82$ & $15-20$ \\
\hline 2. & UDPAa-2 & $95.4 \pm 5.08$ & $84-106$ & $33.0 \pm 1.75$ & $29-36$ & $32.0 \pm 1.70$ & $28-35$ & $19.4 \pm 1.03$ & $17-21$ \\
\hline 3. & UDPAa-3 & $99.3 \pm 5.16$ & $88-111$ & $31.2 \pm 1.62$ & $27-35$ & $35.1 \pm 1.82$ & $31-39$ & $16.0 \pm 0.83$ & $14-17$ \\
\hline 4. & JSL Aa-1 & $89.8 \pm 4.66$ & $79-100$ & $37.8 \pm 1.96$ & $33-42$ & $37.5 \pm 1.95$ & $33-42$ & $17.9 \pm 0.93$ & $16-20$ \\
\hline 5. & JSL Aa-2 & $87.0 \pm 4.54$ & $77-97$ & $36.2 \pm 1.89$ & $32-40$ & $33.0 \pm 1.72$ & $29-36$ & $16.0 \pm 0.83$ & $14-17$ \\
\hline 6. & JSL Aa-3 & $82.3 \pm 3.81$ & 73-92 & $34.0 \pm 1.57$ & $30-38$ & $39.6 \pm 2.54$ & $32-49$ & $15.6 \pm 0.72$ & $13-17$ \\
\hline 7. & JSL Aa-1 & $78.5 \pm 3.63$ & $69-87$ & $28.7 \pm 1.33$ & $25-32$ & $31.4 \pm 1.45$ & $27-35$ & $19.0 \pm 0.88$ & $16-21$ \\
\hline 8. & JSL Aa-2 & $80.0 \pm 4.26$ & $71-89$ & $25.0 \pm 1.33$ & $22-28$ & $38.5 \pm 2.05$ & $34-43$ & $17.0 \pm 0.90$ & $15-19$ \\
\hline 9. & JSL Aa-3 & $82.1 \pm 4.26$ & $73-91$ & $26.4 \pm 1.37$ & $23-29$ & $35.3 \pm 1.38$ & $31-39$ & $17.9 \pm 0.93$ & $16-20$ \\
\hline & $\mathrm{SEm} \pm$ & 0.27 & & 0.10 & & 0.13 & & 0.05 & \\
\hline & $\begin{array}{l}C D \\
(p \leq 0.05)\end{array}$ & 0.76 & & 0.27 & & 0.37 & & 0.15 & \\
\hline & $\mathrm{CV} \%$ & 2.20 & & 2.25 & & 2.68 & & 2.19 & \\
\hline
\end{tabular}

${ }^{*}$ Mean number of 50 conidia and \pm S.D. of mean value

Table 8: Radial growth and cultural characters of nine isolates of A. alternata on RAM

\begin{tabular}{|c|c|c|c|c|}
\hline $\begin{array}{l}\text { Sl. } \\
\text { No. }\end{array}$ & Isolate & $\begin{array}{c}\text { Diame- } \\
\text { ter }^{*}(\mathrm{~mm}) \\
7^{\text {th }} \text { days }\end{array}$ & $\begin{array}{c}\text { Sporulation }^{* *} \\
\left(\times 103 \mathrm{~mm}^{-2}\right. \\
\text { medium })\end{array}$ & Growth characters and colony colour \\
\hline 1. & UDPAa-1 & 84.3 & 10.8 & $\begin{array}{l}\text { Aerial at centre, cottony suppressed near margin with clear zonation, off white } \\
\text { and dull grey in centre, white regular margin. }\end{array}$ \\
\hline 2. & UDPAa-2 & 86.3 & 13.7 & $\begin{array}{l}\text { Felty cottony velvety mycelia growth, submerged uniform off white regular } \\
\text { margin with light grey and white in centre, without zonation. }\end{array}$ \\
\hline 3. & UDPAa-3 & 87.7 & 14.2 & $\begin{array}{l}\text { Cottony felty off white uniform mycelia growth at centre, dull grey and brown } \\
\text { at periphery with off white regular margin. }\end{array}$ \\
\hline 4. & JSL Aa-1 & 75.5 & 10.2 & $\begin{array}{l}\text { Aerial, felty, velvety, suppressed mycelial growth, dull black or light brown in cen- } \\
\text { tre, light zonation present, sometimes dull white near off white irregular margin. }\end{array}$ \\
\hline 5. & JSL Aa-2 & 74.2 & 10.0 & $\begin{array}{l}\text { Aerial cottony velvety suppressed growth, zonation present, light black or dull } \\
\text { grey in centre, sometimes off white with margin. }\end{array}$ \\
\hline 6. & JSL Aa-3 & 72.9 & 9.8 & $\begin{array}{l}\text { Aerial felty, suppressed mycelial growth, dull black or dark grey in centre, } \\
\text { sometimes off white around centre with irregular margin. }\end{array}$ \\
\hline 7. & JLRAa-1 & 82.3 & 10.6 & $\begin{array}{l}\text { Velvety cottony submerged growth without zonation, pure white in centre with } \\
\text { regular margin. }\end{array}$ \\
\hline 8. & JLR Aa-2 & 84.0 & 10.7 & $\begin{array}{l}\text { Felty cottony mycelium growth, olivaceous brown and velvety at centre, light } \\
\text { zonation present with regular white margin. }\end{array}$ \\
\hline 9. & JLR Aa-3 & 84.7 & 9.8 & $\begin{array}{l}\text { Cottony velvety mycelium growth, pure white in centre with irregular off white } \\
\text { margin, light zonation present around centre and sometimes light grey near margin. }\end{array}$ \\
\hline \multicolumn{2}{|c|}{$\operatorname{SEm} \pm$} & 1.37 & 0.30 & \\
\hline \multicolumn{2}{|c|}{$\mathrm{CD}(p \leq 0.05)$} & 4.12 & 0.89 & \\
\hline \multicolumn{2}{|c|}{ CV\% } & 2.93 & 4.52 & \\
\hline
\end{tabular}

": Mean of three replications; ${ }^{* *}$ : Mean of three replications, three from each of the plate 


\begin{tabular}{|c|c|c|c|c|c|c|c|c|c|}
\hline \multirow{3}{*}{ Sl. No. } & \multirow[t]{3}{*}{ Isolate } & \multicolumn{4}{|c|}{ Conidial morphology with beak $(\mu \mathrm{m})$} & \multicolumn{4}{|c|}{ Conidial morphology without beak $(\mu \mathrm{m})$} \\
\hline & & \multicolumn{2}{|c|}{ Length } & \multicolumn{2}{|c|}{ Width } & \multicolumn{2}{|c|}{ Length } & \multicolumn{2}{|c|}{ Width } \\
\hline & & Mean & Range & Mean & Range & Mean & Range & Mean & Range \\
\hline 1. & UDPAa-1 & $27.4 \pm 1.43$ & $24-30$ & $13.4 \pm 0.70$ & $11-15$ & $18.2 \pm 0.95$ & $16-20$ & $11.0 \pm 0.57$ & $9-12$ \\
\hline 2. & UDPAa-2 & $34.0 \pm 1.86$ & $30-40$ & $11.5 \pm 0.53$ & $10-12$ & $29.1 \pm 1.34$ & $25-32$ & $12.2 \pm 0.56$ & $10-13$ \\
\hline 3. & UDPAa-3 & $38.0 \pm 2.02$ & $33-42$ & $12.1 \pm 0.64$ & $10-13$ & $25.1 \pm 1.34$ & $22-28$ & $13.5 \pm 0.72$ & $12-15$ \\
\hline 4. & JSL Aa-1 & $37.3 \pm 1.98$ & $33-41$ & $11.0 \pm 0.58$ & $9-12$ & $24.7 \pm 1.31$ & $22-27$ & $11.8 \pm 0.63$ & 10-13 \\
\hline 5. & JSL Aa-2 & $44.0 \pm 2.28$ & $39-49$ & $12.3 \pm 0.64$ & $11-13$ & $35.3 \pm 2.12$ & $30-40$ & $12.6 \pm 0.65$ & $11-14$ \\
\hline 6. & JSL Aa-3 & $26.5 \pm 1.38$ & $23-29$ & $13.3 \pm 0.69$ & $11-14$ & $20.2 \pm 1.05$ & $17-22$ & $13.9 \pm 0.73$ & $12-15$ \\
\hline 7. & JLRAa-1 & $26.3 \pm 1.22$ & $23-29$ & $10.3 \pm 0.47$ & $9-11$ & $19.9 \pm 0.92$ & $16-24$ & $12.9 \pm 0.60$ & $11-14$ \\
\hline 8. & JLR Aa-2 & $32.8 \pm 1.74$ & $29-36$ & $11.4 \pm 0.60$ & $10-12$ & $28.0 \pm 1.49$ & 24-31 & $9.8 \pm 0.52$ & $8-11$ \\
\hline 9. & JLR Aa-3 & $36.1 \pm 1.87$ & $32-40$ & $13.0 \pm 0.67$ & $11-14$ & $23.9 \pm 1.24$ & $21-26$ & $11.4 \pm 0.59$ & $10-11$ \\
\hline & $\mathrm{SEm} \pm$ & 0.11 & & 0.03 & & 0.09 & & 0.03 & \\
\hline & $\begin{array}{c}\text { CD } \\
(p \leq 0.05)\end{array}$ & 0.31 & & 0.09 & & 0.26 & & 0.09 & \\
\hline & CV\% & 2.39 & & 2.04 & & 2.65 & & 2.08 & \\
\hline
\end{tabular}

${ }^{*}$ Mean number of 50 conidia and \pm S.D. of mean value

the results obtained by Verma et al. (2007), Raja and Reddy (2007) and Tetarwal et al. (2008).

\subsection{Molecular variability analysis using RAPD markers}

A total of 9 random decamer primers (RAPD) were used for RAPD analysis, to generate DNA fingerprint profile of 18 isolates of A. burnsii and A. alternata with a view to detect polymorphism and access molecular diversity amount isolates.

\subsection{Detection of polymorphism by RAPD markers}

Nine RAPD primers were used for the present investigation; all the primers showed amplification. All these 9 primers showed polymorphism whereas; primers OPB-20, OPC-2 and OPG-17 generated maximum 10 bands with PIC 0.31 . 0.34 and 0.33 respectively. A total of 76 amplified bands were obtained and 41 were polymorphic and maximum percentage of polymorphism observed in primer OPC-2 $(80 \%)$ and minimum percentage observed in OPA-19 (25\%), these results exhibits the importance of RAPD markers for diversity analysis. The DNA amplification and polymorphism generated among various genotypes of $A$. burnsii and A. alternata using RAPD primers are presented in Table 10.

The total no. of bands observed for every primer was recorded

\begin{tabular}{|c|c|c|c|c|c|c|c|c|c|}
\hline $\begin{array}{l}\text { Name of } \\
\text { primer }\end{array}$ & Sequences & $\begin{array}{l}\mathrm{GC} \\
(\%)\end{array}$ & $\begin{array}{l}\mathrm{TM} \\
\left({ }^{\circ} \mathrm{C}\right)\end{array}$ & $\begin{array}{c}\text { No. of } \\
\text { amplicons }\end{array}$ & $\begin{array}{l}\text { Polymor- } \\
\text { phic Am- } \\
\text { plicons }\end{array}$ & $\begin{array}{c}\text { Per cent } \\
\text { polymor- } \\
\text { phisms (\%) }\end{array}$ & $\begin{array}{l}\text { Band- } \\
\text { ing } \\
\text { pattern }\end{array}$ & $\begin{array}{l}\text { Primer dis- } \\
\text { criminatory } \\
\text { power (\%) }\end{array}$ & $\begin{array}{c}\text { PIC } \\
\text { values }\end{array}$ \\
\hline OPA-05 & 5`AGGGGTCTTG3` & 60 & 32 & 9 & 5 & 55 & 10 & 0.92 & 0.34 \\
\hline OPA-19 & 5'-CAAACGTCGG-3' & 60 & 32 & 8 & 2 & 25 & 3 & 0.58 & 0.33 \\
\hline OPB-07 & $5^{`}-$ GGTGACGCAG-3` & 70 & 34 & 7 & 5 & 71 & 9 & 0.92 & 0.40 \\
\hline OPB-13 & 5'-TTCCCCCGCT-3’ & 70 & 34 & 6 & 2 & 33 & 4 & 0.70 & 0.41 \\
\hline OPB-19 & 5'-ACCCCCGAAG-3' & 70 & 34 & 8 & 5 & 62 & 9 & 0.89 & 0.30 \\
\hline OPB-20 & 5'-GGACCCTTAC-3' & 60 & 32 & 10 & 5 & 50 & 10 & 0.92 & 0.31 \\
\hline OPC-2 & $5 `$ - GTGAGGCGTC-3` & 70 & 34 & 10 & 8 & 80 & 13 & 0.95 & 0.34 \\
\hline OPG-16 & 5'-AGCGTCCTCC-3’ & 70 & 34 & 8 & 3 & 37 & 10 & 0.89 & 0.45 \\
\hline OPG-17 & 5'-ACGACCGACA3` & 60 & 32 & 10 & 6 & 60 & 11 & 0.95 & 0.33 \\
\hline Total $=9$ & & & & Avg.8.44 & Avg.4.5 & Avg. 52 & & & 0.36 \\
\hline
\end{tabular}


separately and polymorphic bands percentage was calculated subsequently. Average polymorphism across the all 18 isolates was found to be $52 \%$ and overall size of PCR amplified products ranged between $88 \mathrm{bp}$ to $1500 \mathrm{bp}$.

\subsection{Estimation of genetic similarity coefficient and clustering of Alternaria strains based on RAPD profile}

Based on RAPD similarity matrix data (Table 10), the value of similarity coefficient ranged from 0.65 to 0.91 i.e. $65-91 \%$. The average similarity across all the genotypes was found out to be 0.80 showing that the genotypes were highly genetically diverse. Maximum similarity value of 0.91 was observed between isolate Aa-2 JLR and Aa3-JLR. Isolate Aa-3JSL and Ab-1 UDP was found to be genetically diverse with minimum similarity value of 0.65 .

The dendrogram based on RAPD analysis has generated two groups (Figure 1). However, two isolates i.e. AA-3JSL and AB-1 UDP which belongs to Jaisalmer and Udaipur did not cluster with the group. The group consisted five isolates i.e.

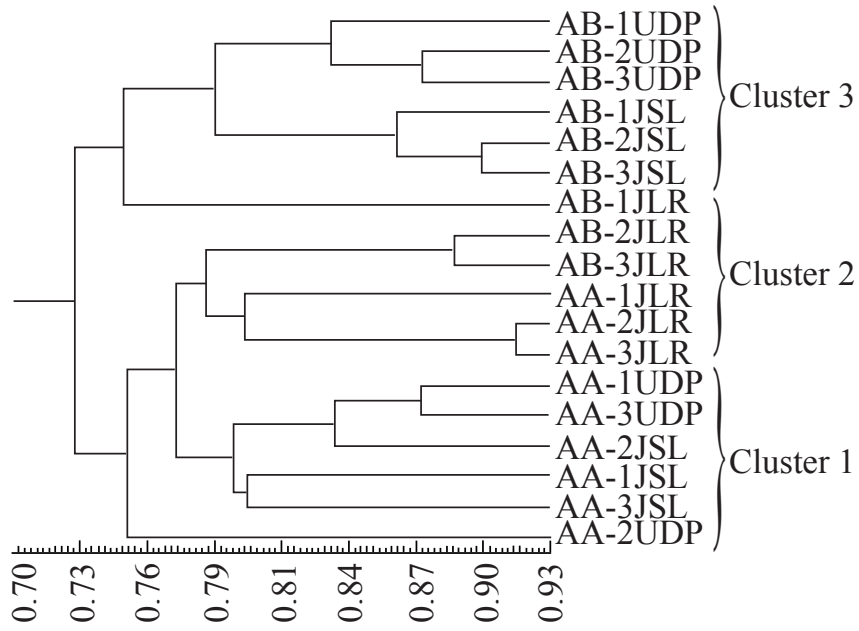

Figure 1: Dendrogram generated through 9 RAPD primer in 18 accession of Fungi Alternaria brunsii (9 accession) and Alternaria alterarta (9 accession)

AB-2 JLR, AB-3 JLR, AA-1 JLR, AA-2 JLR and AA-3 JLRA had higher group similarity of $78.00 \%$. The primers OPC-2 and OPB-07gave $80 \%$ and $71 \%$ polymorphism of the DNA respectively which helped to ascertain variability. Therefore, these primers could be very useful for ascertaining variability among the population of other species of Alternaria. Tigno et al. (2003) studied the genetic variability of 22 isolates of $A$. alternata and $A$. cassiae, obtained from Senna angustifolia, based on RAPD analysis. A total of 491 scorable bands were produced with the use of 28 primers and cluster analysis based on similarities computed through RAPD markers showed 2 distinct genetic groups of isolates related to both species. RAPD analysis proved to be an efficient method for detecting genetic variability of Alternaria alternata and Alternaria cassia isolates occurring in Senna angustifolia, and also for distinguishing Alternaria species. Analysis of RAPD fragment patterns confirmed that when Altemaria isolates are cultured and observed under defined conditions, their phenotypic plasticity is minimized and valid taxonomic separations can be made upon morphological characteristics (Roberts et al., 2000). The genetic variability based on these studies supports the present results distinctly as shown in dendrogram.

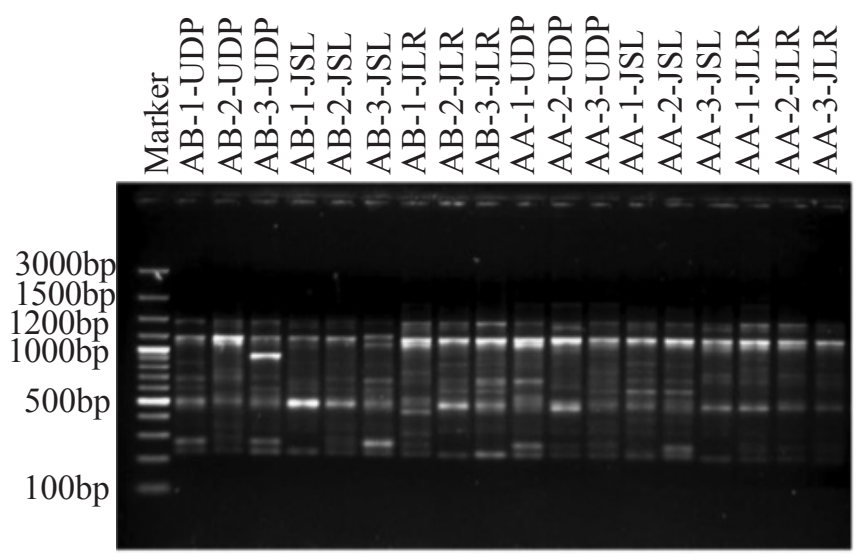

(A) OPA-5: RAPD profile generated for eighteen $A$. brunssii $\&$ A. alternata isolates $(\mathrm{M}=$ Marker)

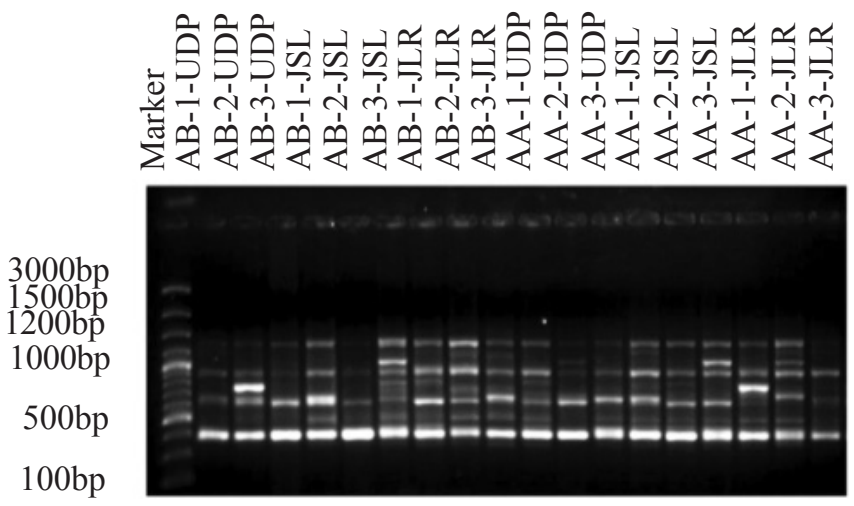

(B) OPB-20: RAPD profile generated for eighteen $A$. brunssii $\&$ A. alternata isolates $(\mathrm{M}=$ Marker $)$

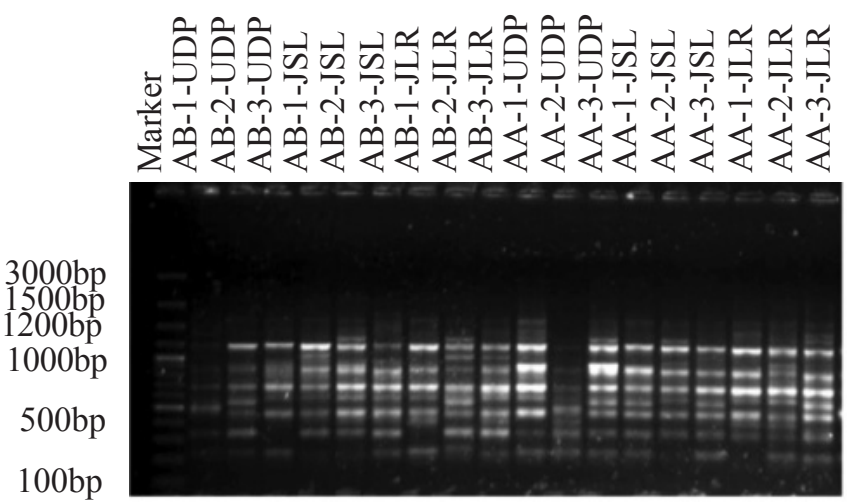

(C) OPG-17: RAPD profile generated for eighteen A. brunssii $\&$ A. alternata isolates $(\mathrm{M}=\mathrm{Marker})$

Plate 10: Molecular characterization of $A$. brunssii and A. alternata isolates by RAPD marker (OPB-20, OPA-5 and OPG-17) 


\section{Conclusion}

Total 18 diverse isolates were used to check the variability and further research on field application using morphological and molecular markers. All isolates of each of $A$. burnsii and $A$. alternata collected from different locations exhibited variations in colony diameter, size, colour of the colony and rate of sporulation on PDA and Richards medium at $28 \pm 1{ }^{\circ} \mathrm{C}$ after 7 days of incubation. Nine RAPD primers were used for the present investigation; average polymorphism across the all 18 isolates was found to be $52 \%$ and overall size of PCR amplified products ranged between $88 \mathrm{bp}$ to $1500 \mathrm{bp}$. Based on RAPD similarity matrix the value of similarity coefficient ranged from 0.65 to 0.91 i.e. $65-91 \%$.

\section{Acknowledgment}

The authors are highly grateful to the Head, Department of Plant Pathology and Dean, Rajasthan College of Agriculture, Udaipur (Raj.) for providing necessary facilities for financial support.

\section{References}

Annonymus, 2016. Indian horticulture Database. National Horticulture Board, Gurgaon, 6.

Doyle, J.J., Doyle, J.L., 1987. A rapid DNA isolation procedure for small quantities of fresh leaf tissue. Phytochemical Bulletin 19, 11-15.

Holliday, P., 1980. Fungal disease of tropical crops. Cambridge University press, Cambridge, U.K. 250.

Pandey, K.K., Pandey, P.K., Rai, M., 2005. Molecular characterization, cultural and pathogenic variability of Alternaria solani isolates. Journal of Mycology and Plant Pathology 35, 483.
Pryor, B.M., Michailides, T.J., 2002. Morphological, pathogenic and molecular characterization of Alternaria isolates associated with Alternaria late blight of pistachio. Phytopathology 92, 406-416.

Raja, P., Reddy, A.V.R., 2007. Morphological and biological variability of Alternaria spp. causing leaf spot and fruit rot of brinjal. Journal of Mycology and Plant Pathology 37, 336-338.

Rastogi, A., 1993. Occurance and transmission of Alternaria burnsii in cumin seeds grown in Rajasthan. J. Ind. Bot. Soc. Abst., 72 (Suppl.) V- 13.

Roberts, R.G., Reymond, S.T., Andersen, B., 2000. RAPD fragment pattern analysis and morphological segregation of small-spored Alternaria species and species groups. Mycological Research 104, 151-160.

Rohlf, F.J., 1998. NTSYS-pc numerical taxonomy and multivariate analysis system. Version 2.02. Exeter Publications Setauket, New York.

Singh, S., Trivedi, A., Mathur, K., Padamini, R., 2015. Assessment of yield loss of cumin (Cuminum cyminum) caused by Alternaria leaf blight and pathogen recovery from infected seeds. Indian Phytopatholgy 68, 350-352.

Tetarwal, M.L., Rai, P.K., Shekhawat, K.S., 2008. Morphological and pathogenic variability of Alternaria alternata infecting senna. Journal of Mycology and Plant Pathology 38, 375-377.

Tigno, M.S., Aljanabi, S., Mello, S.C.M., 2003. Genetic variability of Branzilion Alternaria spp. isolates as revealed by RAPD analysis. Brazilian Journal of Microbiology 34, 117-119.

Verma, P.K., Singh, S., Gandhi, S.K., 2007. Variability among Alternaria solani isolates causing early blight of tomato. Indian Phytopatholgy 60, 180-186. 